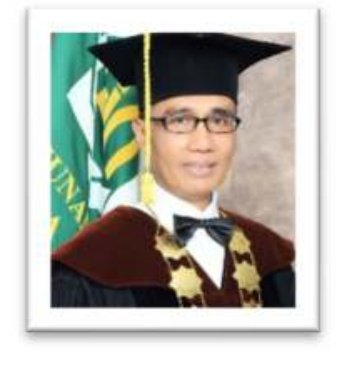

\title{
WELCOME WORD BY THE DEAN
}

The International Conference of Da'wa and Communication (ICON-DAC) 2019 was motivated by the response to the dynamics of socio-religious issues and the need for the development of da'wa and communication science. As it is known, the growing issues related to da'wa eventually have a local, national, and regional context although a certain issue may be relevant to all contexts. Such as the issue of massive internet, cyber and social media use that has destructive impact; exposing the contents of cruelties, exploitations, racism, discrimination, marginalism, extremism, sectarianism, and other abuses. Such issues massively arise during political contestation in both national and local election agendas. Non-Muslim in majority Muslim countries even feel unrest and insecure during a campaign period when a certain Muslim group of political contestants bring the sentiment of Islam for their propaganda.

The grand design of the da'wa will never be there unless going through a sharing of ideas of all its stakeholders among academics and activists in the interactive and discussion forums. The dialogue among participants will ultimately lead to the constructive insight of da'wa resulted from the convergence of rich theories and practical experiences of participants. Through the process of dialogue between stakeholders the new insight of da'wa is hoped can be down earthed and applicable and becomes useful for the activist of da'wa in responding the demand of contemporaries. For that purpose, this conference is held for the birth of the grand design of da'wa that combines all models, strategies, technics, and methods of communication under the core value of Da'wa Rahmatan li al -'Alamin (Da'wa as the Mercy to the Worlds).

In accordance with the background, the ICON-DAC 2019 aims for: (1) sharing the ideas on concepts of da'wa and civilized communication, (2) becoming an effective forum for dialoguing da'wa issues participated by all stakeholders among mass organisation representatives, activist $\left(d a^{\prime} i\right)$, people ( $\left.\operatorname{mad}^{\prime} u\right)$ and academics, and (3) building an understanding on da'wa and civilized communication as an instrument of the grand design of human life. While the output to be achieved is all papers will be published in the ISSN Proceeding and the selected ones will be published in the international indexed journals. For this purpose and output, the Da'wa and Communication Faculty of UIN Sunan Ampel Surabaya took the initiative to organize ICON-DAC.

The event can be progressively continued for its increasing contribution to the development of sciences, especially the science of da'wa and communication studies. As the reviewer team reports, in the ICON-DAC 2019 there are seven keynote speaker papers and 54 papers by presenters from 22 domestic and foreign universities. This is an international conference achievement, for the first time, which should be appreciated. We consider that the event is an important event for the academic world. Therefore, we hope that the event can be held regularly as an annual conference. This expectation was also conveyed by some of the ICON-DAC 2019 presenters. We hope that the future ICON-DAC events will be able to explore the most actual and innovative ideas, thoughts and research results.

For the implementation and success of ICON-DAC 2019, we express our highest appreciation and thanks to all parties involved in it, especially to: Rector of UIN Sunan Ampel (Prof. Masdar Hilmy, S.Ag, MA, Ph.D) and his staff, Governor of East Java (Ms. Khofifah Indar Parawansa) as the honorable speaker, all keynote speakers, presenters, participants, lecturer 
colleagues, education staff, committee, students, affiliations, and supporters. The supporters were (1) Jurnal Komunikasi Islam, Da'wa and Communication Faculty of UIN Sunan Ampel Surabaya, (2) Center for Southeast Asian Social Studies (CESASS), Gajah Mada University, Yogyakarta, (3) IKAT: The Indonesian Journal of Southeast Asian Studies, (4) International Journal of Multicultural and Multireligious Understanding (IJMMU), (5) Perkumpulan Pengelola Jurnal Ilmu Dakwah (PPJID), (6) Persada Indonesia: Haji Plus-Umrah-Halal Tour, (7) Bank Jatim Syariah, Surabaya Branch Office, (8) Bank Tabungan Negara, Surabaya UINSA Branch Office, (9) Bank Banten, Surabaya Branch Office.

In addition, we apologize to all parties for our oversight and the inconvenience of all participants and contributors. Hopefully this first experience will be a valuable pearl for this event and similar events in the following periods.

Surabaya, September 27, 2019

The Dean of Da'wa and Communication Faculty, State Islamic University of Sunan Ampel Surabaya,

Dr. H. Abdul Halim, M.Ag 